\title{
有機薄膜のエピタキシャル成長指針
}

\author{
多田博 一**小間篤 \\ 東京大学大学院理学系研究科 -113 東京都文京区本郷 7-3-1
}

(1993 年 7 月 14 日 受理)

\section{Guiding Principles for Epitaxial Growth of Organic Thin Films}

\author{
Hirokazu TADA* and Atsushi Koma \\ Department of Chemistry, School of Science, University of Tokyo \\ 7-3-1 Hongo, Bunkyo-ku, Tokyo 113
}

(Received July 14, 1993)

\begin{abstract}
分子線エピタキシー $(\mathrm{MBE})$ 法を用いて, アルカリハライド $(\mathrm{AH})$ や遷移金属ダイカルコゲナイド $\left(\mathrm{TX}_{2}\right)$ の清浄表面に, さまざまな有機物の超薄膜を作製し, 反射高速電子回折 (RHEED) を用いて, 成膜第 1 層目 の分子配列を調べた。基板の格子定数を系統的に変化させて薄膜成長を行った結果, 以下のような特徴を見 出した。(1)多くの有機物は, $\mathrm{TX}_{2}$ 䢃開面に代表されるファンデルワールス表面で秩序構造をむって配列 する。(2)不対電子をむつ窒素原子を有するなど, 分子内に電荷分布をむつあのは, AH 上で静電的相互作 用を介して配列させうる。(3)平面型分子は分子面を基板に平行にして配向する。(4)有機分子はできるだ け隙間を少なくするようにパッキングして配列する。( 5 )その際, 分子の組む格子と基板の原子配列との間 に, 整合関係がある場合, エピタキシャル成長が促進される。(6)ファンデルワールス表面では整合性が満 たされない場合でもエピタキシャル成長が起とる。その場合, 分子の組む格子の軸は, 基板の主軸と一致す るととが多い。

これらの特徵は，無機基板上に作製した有機薄膜の分子配列・分子配向を予測するとと屯に，さまざまな 有機物のエピタキシャル成長を可能にする指針になると考えられる。
\end{abstract}

\section{1.はじめに}

ここ数年,「ナノ・テクノロジー」あるいは「ナノ・ス トラクチャー」というととばを目にする。現在のいわゆ る「マイクロ」素子の性能に飽き足らず，より高密度 化, 高速化を図るため, 原子レベルで構造制御された素 子を構築しようとする試みである。

そのような中で, 有機分子を構成要素とする「分子素 子」の実現が提唱され始めた。無機材料の微細化・集積 化には，自ずと限界があるためである。有機物は，官能 基の違いひとつで異なる特性を示す。しかも, 個々の分

* 1993 年 10 月より通信総合研究所関西先端研究センター 恶651-24 神戸市西区岩岡町岩岡 588-2

* Communication Research Laboratory, Kansai Advanced Research Center, 588-2 Iwaoka, Nishi-ku, Kobe 651-24
子がそれぞれの特性を有するため, 高密度化が期待され る。また，特性を決めているのは緩く束縛されている $\pi$ 電子であるため, 外部電場に対する高速の応答が可能で ある。乙のような特徴を活かして, ソリトンやトンネル 電子, エキシトン, プロトンなどを情報の担い手とする 素子が考案された ${ }^{1}$ 。乙うした「分子素子」の概念は非 常に魅力的なものであったが, 現在までのとてろ実現に は至っておらず,「紙上でのみ動作する素子」という批 判は免れない。解決しなければならない技術的な問題が あまりにも多いのに加え，「結晶の分子配列を支配する 要因は何であるか」という基本的な知見が著しく不足し ている。

一方で，乙うした研究の途上，集合体としての有機物 の屯つ特性に改めて注意が向けられ, 非線形光学効果や 光電変換機能など,「次世代の機能材料」としての有機 物の有用性が示された。乙れらの機能は, 分子集合体の 
構造と結晶性に大きく依存する。機能の発現機構を考察 するうえでも，有機分子を分子レベルで制御して規則正 しく配列し，その構造と物性の関係を明らかにすること の重要性が認識されつつある。特に「ナノ」サイズでの 構造制御と物性発現のための薄膜化技術と無機物質をも 組合せた複合化技術の確立が大きな課題である。

こうした薄膜を作製する手法は，液相加ら成膜する湿 式法と気相から成膜する乾式法に大別される。前者の代 表がラングミュアーブロジェット (LB) 法であり，後 者には, 真空蒸着法, 分子線エピタキシー $(\mathrm{MBE})$ 法な どがある。MBE 法は，無機半導体作製技術として，超 高真空技術の進歩と共に急速に発展した手法である。こ の方法を有機物に適用することにより，基板の原子配列 の影響を強く受けた構造をもち，結晶性の良い薄膜が作 製できる点で期待が寄せられている。

\section{2. 有機エピタキシャル薄膜の研究の歴史}

「エピタキシャル成長」ということばは, 1928 年に Royer ${ }^{2)}$ によって用いられたのが最初である。その後 1956 年に, Pashley によって総説が書かれた かけに，このととばが広く使われるようになった。

有機分子に関しては, 1962 年に Nature に揭載された

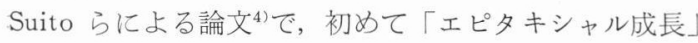
という語が用いられたようである。彼らは, 雲母上に真 空蒸着したフタロシアニンやインダントロン（染料の一 種）などの薄膜を，透過電子線回折 (TED) や透過電子 顕微鏡 (TEM) によって観察し, 下地との方位関係を定 めている ${ }^{4 \sim 6)}$ 。その後この手法は, 植田, 芦田, 小林, 八 瀬らのグループに受け継がれ，現在に至るまで数多くの 報告がなされている 化水素についてその結晶成長過程を独自の手法で追跡し ている ${ }^{24-28)}$ 。外国では Somorjai らが，低速電子線回折 (LEED) を用いて, 金属の清浄表面上に蒸着したさまざ まな有機単分子膜の構造解析を行っている ${ }^{29) 。 乙 れ ら の ~}$ 先駆的な仕事により，有機蒸着膜の構造は，下地基板の 格子定数や対称性，表面の污れ，基板温度，成膜速度な どの影響を非常に強く受けることが示された。

1980 年代に入り, 前述のように機能性材料としての 有機物に注目が集められると，技術的には先行していた 無機半導体の研究手法を積極的に取り入れることになっ た。すなわち試料の純度や薄膜作製時の不純物の混入に 細心の注意が払われるようになり，超高真空中で成膜す る MBE 法を適用し, 基板温度や成膜速度と薄膜の構造 や結晶性との関連が，あらゆる評価手段を用いて検討さ れるようになった。このような目的意識をもつ「有機超 薄膜」の研究が, 本研究 30 -37)のほか, 理化学研究所の
原らのグループ38), 分子科学研究所の丸山らのグルー プ39 42) そよって開始されており，また，外国でもいくつ かのグループから，報告が出始めている ${ }^{43 \sim 46) 。}$

\section{3. 本研究の目的と特徵}

本研究では，有機エピタキシャル膜の成長の要因を検 討し，指針を与えることを目的とした。そのため，天然 に存在しない物質を含め, 種々の基板を $\mathrm{MBE}$ 法により 作製し，基板の格子定数や対称性の影響を系統的に調べ るととを試みた。また，エピタキシャル成長の初期段階 を追跡するため, 構造解析には成膜中の構造変化を，第 1 層目から直接観察できる反射高速電子回折 (RHEED) を用いた。

さらに作製した超薄膜を大気に曝すととなく各種分析 装置に移送し, 角度分解紫外光電子分光 (ARUPS) や可 視吸収スペクトルなどの分光測定，走査トンネル電子顕 微鏡 $(\mathrm{STM})$ による分子像観察を超高真空中で行った。

\section{4. 実 験}

図 1 亿装置の概略を示した。基板導入室, 成長室, 分 析室および光学測定室の四つの真空チャンバーからな り，それぞれはゲートバルブを介して結ばれている。到 達真空度は，それぞれ $5 \times 10^{-6} \mathrm{~Pa}, 2 \times 10^{-7} \mathrm{~Pa}, 5 \times 10^{-8}$ $\mathrm{Pa}, 2 \times 10^{-7} \mathrm{~Pa}$ である。

基板導入室は, 他の真空装置との間で, 基板および薄

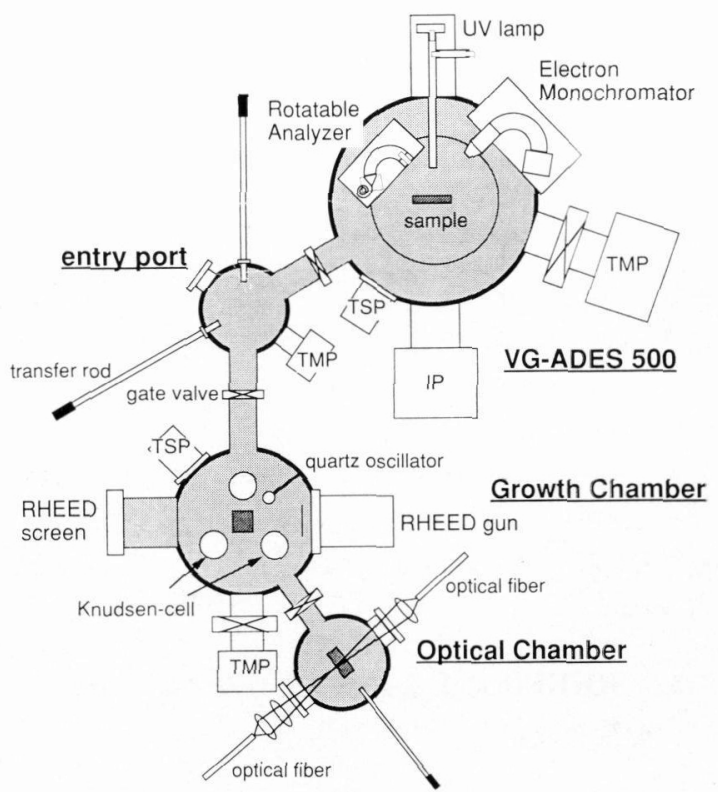

図 1 実験装置の概要

TMP：ターボ分子ポンプ, IP：イオンポンプ, TSP : チタンサブリメーションポンプ 
膜試料の受渡しをするための中継点としての役目を果た すと共に，試料の予備加熱や，金の蒸着などの処理を行 う。

分析室として, Vacuum Generators 社製の角度分解 電子分光装置 (ADES 500) が連結されている。低速電子 線回折装置および He 放電紫外光源が装置されており, 基板および薄膜の角度分解紫外光電子分光 (ARUPS) 測 定を行う。

成長室には, 試料の蒸発源として, 最高 3 基の Knudsen セルが取り付けられ、シャッター制御により, 交互 積首膜の作製む可能である。薄膜の成長速度および成長 量は, 基板近くにある水晶振動子の周波数変化をモ二タ 一しながら制御する。基板は $X, Y, Z$ 方向の移動, 面 内回転およびチルト運動の可能なマニピュレーターに保 持する。タンタル製のヒーターにより, 基板を背面から 加熱し, 約 $500^{\circ} \mathrm{C}$ まで基板温度を上げるととが可能であ る。また液体窒素溜を装着するととにより, $-150^{\circ} \mathrm{C}$ 程 度に冷却可能である。20 kV 亿加速された電子線を表面 すれす机谢し，対向する位置にある蛍光スクリーン 上に結ぶ RHEED 像を観察する。

光学測定室では, 光ファイバーを用い, ビューポート を通して白色光を導入する。試料を透過した光をレンズ を用いてファイバーに集光し分光器 (大塚電子, 瞬間マ ルチ測光システム, MCPD-1100) に導く。試料ホルダー は液体窒素で $-140^{\circ} \mathrm{C}$ に泠却できる。

試料としては金属フタロシアニン (MPc, M=VO, $\mathrm{Pb}, \mathrm{AlCl}, \mathrm{Cu}$ など, $\left.\mathrm{P} c=\mathrm{C}_{32} \mathrm{H}_{16} \mathrm{~N}_{8}\right)$ をはじめコロネン, TCNQ 誘導体など, 機能性材料として期待されている あのを選んだ。基板としてはアルカリハライド (001) 面 (4 回対称表面) や遷移金属ダイカルコゲナイド (0001) 面（6回対称表面）を用いた。どちらもさまざまな格子 定数の物質が存在し, 格子定数を系統的に変化させて, 成長膜の構造変化を調べるととが可能である。単結晶の 入手が困難な物質については，適当な基板の上にその薄 膜をへテロエピタキシャル成長して使用した。また，Si (111）面や GaAs(111) 面のダングリングボンドを，そ れぞれ水素原子およびセレン原子で終端した基板につい ても，MPcの エピタキシャル成長を試みた。以下では， 種々の基板上での MPc 超薄膜のエピタキシャル成長に ついて紹介する。

\section{RHEED による金属フタロシアニン分子 配列の決定}

\section{1 アルカリハライド基板上}

$\mathrm{MPc}$ は, 室温での蒸気圧が低く, 耐熱性にも優机て いるため, 古くから真空蒸着法による薄膜の作製が行わ

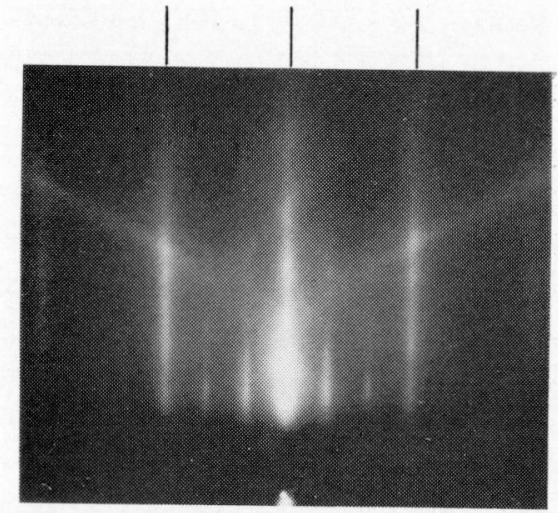

図 $2 \mathrm{KBr}(001)$ 䴙開面上に成長した $\mathrm{VOP}$ 超薄 膜の RHEED 像。電子線の入射方向は基板の [100] 軸に平行。写真の上の線は基板のストリー ク位置を示す

れてきた。また, MPc は電子線の照射にも比較的強い 物質であり, 電子線回折によるエピタキシー現象が調べ られた最初の有機分子であある( ${ }^{4}$ 。アルカリ八ライドの 水溶性は TED や TEM 用基板として好都合であるた め, 有機エピタキシャル膜の基板として頻繁に使用され ている。

これらの膜は, いずれも数十 $\mathrm{nm}$ の膜厚をもち, TED から導かれるこれらの膜の格子のいくつかは, 下地基板 の原子配列とは不整合になっている。Dann らは，成膜 1 層目は整合性があるが, 膜厚が厚くなるにつれて分子 間距離が変化しバルクのそれに近づくためであると考え ている ${ }^{399}$ 。本研究では, 特に膜厚 1 層以下から数層程度 の領域での格子構造を RHEED を用いて調べ, 成長要 因之成膜過程に関する考察老行った。

図 2 に $\mathrm{KBr}(001)$ 嬖開面上に成長した $\mathrm{VOP}$ 超薄膜 の RHEED 像を示す 30 )。電子線の入射方向は基板の [100］軸に平行である。基板のストリークをちょうど 3 等分する位置にVOPc 由来のストリークが現れている。

他の方向から観察した RHEED 像も考慮すると, $\mathrm{VOPc}$ 分子は $\mathrm{KBr}$ 上で図 $3(\mathrm{a})$ の破線で示した正方格 子 $(3 \times 3, \mathrm{~A}$ タイプと呼ぶ $)$ を組んで並んでいることが わかった。基板とは整合性があり，分子間距離は 1.40 $\mathrm{nm}$ となる。乙れは VOPc 分子が分子面を基板に平行に して並ぶのに十分な間隔である。そこで，図では分子が 平行配向しているように描いた。また, 中心金属を八口 ゲンアニオンの上に置いた。RHEED からは, 分子の組 む単位格子がわかるのみで, 基板上での分子の位置や配 向に関する情報を得るととは困難である。図のような配 列モデルは, 後述する実験結果などを考虑して描いたも のである。 


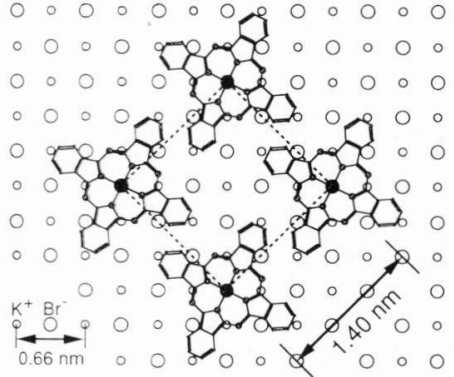

(a) $\mathrm{VOPc} / \mathrm{KBr}$

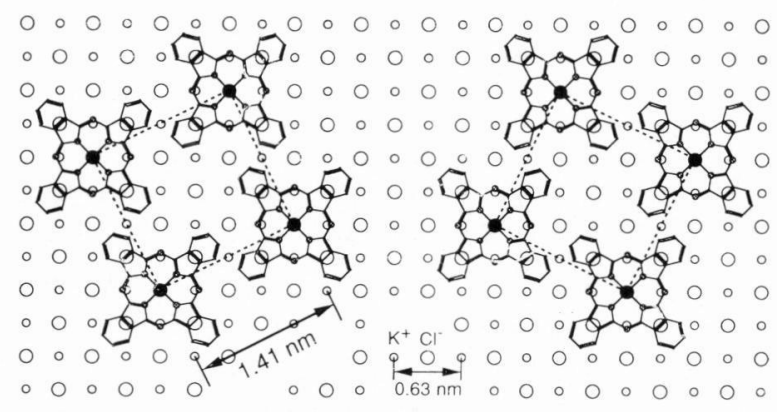

(b) $\mathrm{VOPc} / \mathrm{KCl}$

図 3 ( a $) \mathrm{KBr}$ 上, (b) $\mathrm{KCl}$ 上での $\mathrm{VOP}$ 分子の並び方のモデル RHEED からは図の破線で示した単位格子が決められる

$\mathrm{KCl}$ 上では異なる像を与え, 図 $3(\mathrm{~b})$ のような二つ の等価な正方格子 $\left(\sqrt{10} \times \sqrt{10}-R \pm 18.4^{\circ}, \mathrm{B}\right.$ タイプ) を組むことがわかった。分子間距離は $1.41 \mathrm{~nm}$ である。 $\mathrm{KBr}$ 上, $\mathrm{KCl}$ 上の $\mathrm{VOPc}$ 膜は, 膜厚数十分子層まで同 様の RHEED 像が観測される。ただし, 膜厚が数分子

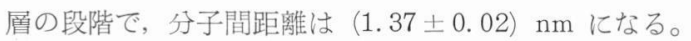
したがって，これらの膜を TEM や TED で観測した場 合，基板とは不整合になる。

$\mathrm{NaCl}$ 上であ $\mathrm{B}$ タイプとなり，とのときの分子間距離 は $1.26 \mathrm{~nm}$ である。しかし RHEED 像は弱く, 膜厚が 数分子層の段階で八ロー像となる。これは, $\mathrm{NaCl}$ 上で の分子間距離が小さく, 分子間に反発力が働き, 秩序構 造領域が大きくなれないためと思われる。
他の MPc および酸化バナジゥムナフタロシアニン (VONc) についての結果は表 1 にまとめた。表 1 には他 のグループによる TEM・TED を用いた構造解析の結 果も示した。バルクでは，それぞれ異なる構造をむつ $\mathrm{MPc}$ が， AH 上では図 4 亿示した A, B , C $(\sqrt{13} \times \sqrt{13}$ $\left.-R \pm 33.7^{\circ}\right)$ のタイプの正方格子のどれかをとること は興味深い*。第 1 層目は基板と整合な格子を組んでお り, これは, 分子の位置を決める第一の要因が, 基板と 分子の間に働く静電相互作用であることを示している。

図 3 では, 中心金属を八ロゲンアニオンの上に置くモ デルを考えた。X線光電子分光および Hückel 法を用い た計算によると， MPc の中心金属は， 0.4〜0.9 e 正に 帯電しており, ブリッジ位置の窒素原子は $0.2 \mathrm{e}$ ほど負

表 1 本研究および他のグループによるアルカリハライド上での金属フタロシアニンの並び方のまとめ

\begin{tabular}{|c|c|c|c|c|c|c|c|c|c|c|c|c|c|}
\hline & \multicolumn{5}{|c|}{ RHEED study (ultrathin film) } & \multicolumn{8}{|c|}{ TEM \& TED study (thick film) } \\
\hline reference & $\begin{array}{c}\mathrm{PbPc} \\
(33)\end{array}$ & $\begin{array}{c}\text { VOPc } \\
(30)\end{array}$ & $\underset{(35)}{\mathrm{AlPcCl}}$ & VONc & $\mathrm{CuPc}$ & $\begin{array}{c}(\mathrm{A} 1 \mathrm{PcF}) \mathrm{n} \\
(39)\end{array}$ & $\underset{(42)}{\mathrm{VOPc}}$ & $\mid \begin{array}{c}\mathrm{AlPcCl} \\
(42)\end{array}$ & $\underset{(40)}{\mathrm{LuPc}_{2}}$ & $\underset{(47)}{\operatorname{LnP}_{2}}$ & $\underset{(48)}{\operatorname{LnPc}_{2}}$ & $\begin{array}{c}\text { VONc } \\
(19)\end{array}$ & $\begin{array}{c}\mathrm{ZnNc}_{\mathrm{nN}} \\
(20)\end{array}$ \\
\hline $\begin{array}{l}\mathrm{Rbl} \\
0.73\end{array}$ & & & & $\begin{array}{c}\text { B } \\
\text { 1. } 64\end{array}$ & & & & & & & & & \\
\hline $\begin{array}{l}\mathrm{K} 1 \\
0.71\end{array}$ & & & $\begin{array}{c}\mathrm{A} \\
1.50\end{array}$ & $\begin{array}{c}\text { B } \\
1.58\end{array}$ & & & & $\mathrm{~A}^{* * * *}$ & & & & & \\
\hline $\begin{array}{l}\mathrm{KBr} \\
0.66\end{array}$ & $\begin{array}{c}\mathrm{A}\left(+\mathrm{B}^{\prime}\right) \\
1.40\end{array}$ & $\begin{array}{c}\mathrm{A} \\
1.40\end{array}$ & $\begin{array}{c}\text { B } \\
1.48\end{array}$ & $\begin{array}{r}\text { B* } \\
1.48\end{array}$ & $\begin{array}{l}\alpha \text {-type } \\
\text { crystal }\end{array}$ & $\begin{array}{c}\mathrm{A}^{\prime} \\
1.27\end{array}$ & $\mathrm{~A} * * * *$ & $\mathrm{~B} * * * *$ & $\mathrm{~B} * * * *$ & & & & \\
\hline $\begin{array}{l}\mathrm{KCl} \\
0.63\end{array}$ & $\begin{array}{c}\text { B } \\
1.41\end{array}$ & 1. 41 & $\begin{array}{c}\text { B } \\
1.41\end{array}$ & $\begin{array}{l}\mathrm{C}^{* *} \\
1.60\end{array}$ & $\begin{array}{r}\alpha \text {-type } \\
\mathrm{B} * * *\end{array}$ & $\begin{array}{r}\mathrm{B}^{\prime} \\
1.27\end{array}$ & $\mathrm{~B} * * * *$ & B $* * * *$ & & $\begin{array}{r}B^{\prime} \\
1.35\end{array}$ & $\begin{array}{l}\mathrm{B} * * * * \\
1.40\end{array}$ & $\begin{array}{c}\mathrm{C}^{\prime} \\
1.58\end{array}$ & \\
\hline $\begin{array}{c}\mathrm{NaCl} \\
0.56\end{array}$ & $\begin{array}{c}\text { B } \\
1.26\end{array}$ & $\begin{array}{c}\text { B } \\
1.26\end{array}$ & $\begin{array}{c}\mathrm{C} \\
1.43\end{array}$ & & $\begin{array}{l}\alpha \text {-type } \\
\text { crystal }\end{array}$ & & $\mathrm{B} * * * *$ & $\mathrm{C}^{* * * *}$ & & & & & $\begin{array}{l}4 \times 4 \\
1.58\end{array}$ \\
\hline
\end{tabular}

空欄は未実験・未報告。Pc: phthalocyanine, Nc: naphthalocyanine。

枠内の A， B，C は格子タイプを表わす。下段の数值は格子の一辺の長さ（分子間距離）を表わす (単位は $\mathrm{nm}$ )。 プライム(') は格子が下地基板と不整合であるととを表わす。

*: 基板加熱時Cタイプの格子となる。**: 整合・不整合が決定できなかった。***: 基板冷却時 $\mathrm{B}$ タイ゚の格子を組むととを示 す RHEED 像となる。****：文献中に整合・不整合の別が明記されていない。

* 神戸大の柳らは, $\mathrm{ZnNc}$ 分子が $\mathrm{NaCl}$ 上で $4 \times 4$ の構造をむつととを報告しており20), さらに多様な格子型が存在する可能性 がある。なお，Woodの記号は，図 4（a）の矢印で示した基本ベクトルを用いて表わしている。 


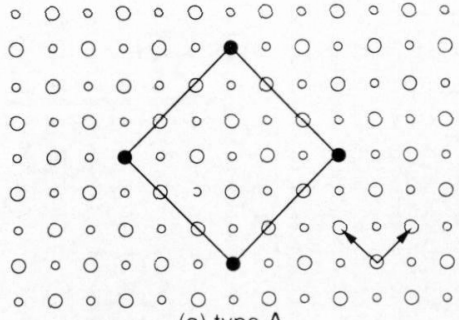

(a) type A

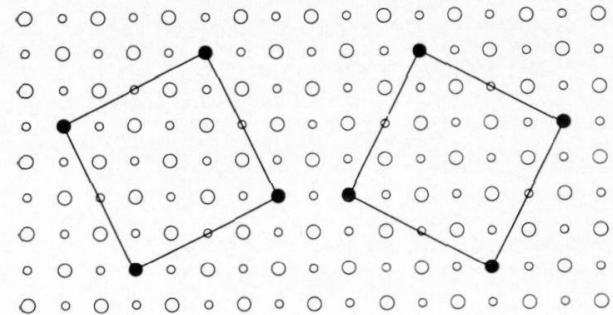

(b) type B

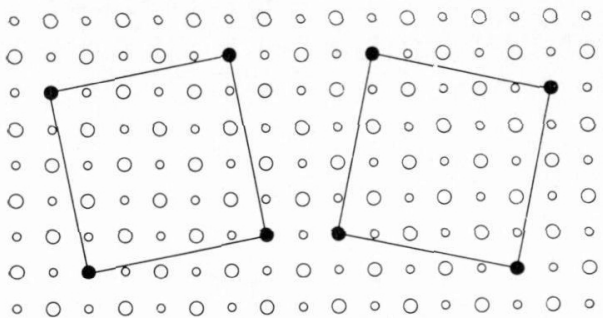

(c) type C

図 4 三つのタイプの正方格子

に帯電している ${ }^{49)}$ 。中心原子に付加した酸素原子や塩素 原子とアルカリカチオンの接触を考えることあできる が，（i P PbPc のように付加原子のない分子も同様の配 列をするとと，（ii）中心金属一ハロゲンアニオン接触モ デルでは，ブリッジ位置の窒素原子がアルカリ金属カチ オンに近づくことができること，の 2 点老考慮した。

(ii)は, 芦田によって提案された配置であり ${ }^{8)}, \mathrm{MPc}$ 分子にとって, 静電的に最む安定であると思わ机る。そ れぞれの分子にこのような配置を取らせると, B タイプ の格子が分子配列に好都合であることがわかる。すなわ ち，ひとつの分子の凸部であるべンゼン環が隣の分子の 凹部に入り込み，立体障害を避けることができる。

一般に，有機分子が結晶を造るときには，ひとつの分 子の凸部が，隣接分子の凹部に入り込んで詰まっていく ことが知られている。この様子を，木工作の「蟻つぎ (dove-tail)」に見立てて dove-tail 原理之呼んでいる50)。 Somorjai 引は, 金属上の有機単分子膜の LEED 像加 ら，乙の原理は金属基板上の薄膜についてああてはまる としている ${ }^{29)}$ 。LEED 像から求められる格子の大きさか ら推定して，ほとんどの有機分子は，分子面を金属表面
に平行になるように配置し，凸部と凹部をうまくかみあ わせて配列すると考えている。

MPc の場合，中心金属とブリッジ位置の窒素を結ぶ 分子軸と格子軸のなす角が約 $25^{\circ}$ のときに, dove-tail 原理を満たし，分子間ポテンシャルを小さくすることが できると考えられる。Bタイプの格子では，この配列を 保ったまま, 窒素原子がアルカリ金属カチオン上に位置 するととができ，静電ポテンシャルも小さくなるととが わかる。 $\mathrm{MPc}$ 分子はB夕イプの格子において, 分子間 距離を $10 \%$ ほど変化させている。表 1 より, MPc 分子 は許される分子間距離を取れる限り，Bタイプの格子を とりやすいととがわかる。AH の格子定数が大きくな り，Bタイプの格子では分子間距離が大きくなりすぎる

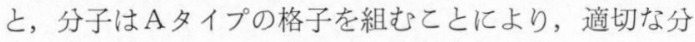
子間距離を維持しようとする。Aタイプの格子では, 心゙ ンゼン環同士の立体障害を避けるため, 分子が面内回軽 する必要が生じ, 窒素原子はアルカリ金属カチオン上に はない。以上より, $\mathrm{AH}$ 上での $\mathrm{MPc}$ 分子の配列を決め る要因は，中心金属一八ロゲンアニオンの静電相互作 用, 分子間相互作用, 窒素原子一アルカリカチオンの静 電相互作用の順であると考えられる。

\section{2 遷移金属ダイカルコゲナイド基板上}

$\mathrm{MoS}_{2}$ をはじめとする遷移金属ダイカルコゲナイド は, 層状構造をむち, 層間は弱いファンデルワールスカ で結合している。その辟開面にはダングリングボンドが 存在せず，化学的に不活性である。こうしたファンデル ワールス表面を有機薄膜の基板として用いた例として は，容易に入手しやすい $\mathrm{MoS}_{2}$ 天然鉱物 ${ }^{38,43,45)}$ や雲 母 $^{4-2,28)}$, グラファイト ${ }^{10,43,46)}$ などがあるが，基板の格 子定数を系統的に変化させて, ファンデルワールス表面 での有機薄膜成長の特徵を調べた例はない。

われわれの研究室では， $\mathrm{MoS}_{2}$ 上あるいはダングリン グボンドを終端した $\mathrm{GaAs}$ や $\mathrm{Si}$ 上に, 種々の層状物質 をへテロエピタキシャル成長させる方法として，ファン デルワールスエピタキシー法を確立した ${ }^{511}$ 。この手法で は，格子整合条件の満たされない物質間でのへテロ成長 が可能となり, 有機固体のように格子定数が無機物より 大きく, 分子間が弱いファンデルワールスカによって凝 集する系にあ適用できると考元られる。格子定数の異な る $\mathrm{MoS}_{2}$ や $\mathrm{NbSe}_{2}, \mathrm{GaSe}$ 上に $\mathrm{MPc}$ 薄膜を作製し, エ ピタキシャル成長の要因を検討した。なお, $\mathrm{NbSe}_{2}$, GaSe は GaAs (111) 面上にヘテロ成長したものを用い $t^{52,53)}$

図 5 は $\mathrm{MoS}_{2}$ 上での $\mathrm{VOPc}$ 分子の並び方である。分 子は基板の主軸である [11 20$]$ 軸と辺を平行にする正方 格子在組んで配列しているととがわかった。対称性から 


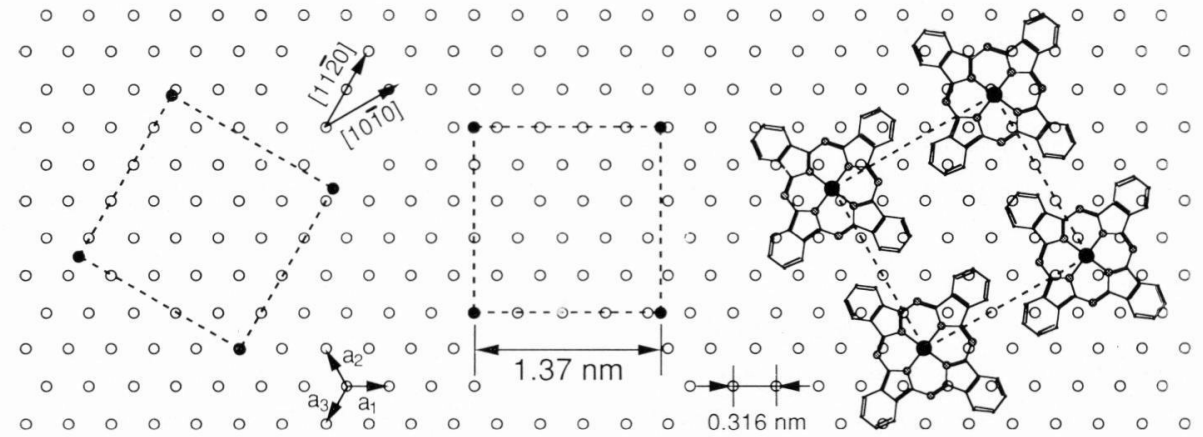

図 $5 \mathrm{MoS}_{2}$ 䢃開面上での $\mathrm{VOP}$ 分子の並び方

等価な格子は三つ存在する。基板との整合性はなく，ス トリーク間隔から算出される分子間距離は $(1.37 \pm 0.2)$ $\mathrm{nm}$ である。この大きさは, 眓のように分子が分子面を 基板に平行にして位置するのにちょうどの大きさであ る。この格子型を「軸平行型」と呼ぶ。

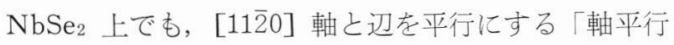
型」の正方格子を組む。やはり基板との整合性はなく, 分子間距離は $(1.37 \pm 0.2) \mathrm{nm}$ と計算された。

GaSe 上では, 図6 のようにほぼ正方形に近い菱形の 格子を組んでいるととがわかった。基板とは整合性があ り, 分子間距離は, 格子定数 $(0.376 \mathrm{~nm}) の \sqrt{13}$ 倍の 1. $355 \mathrm{~nm}$ となる。この格子を「整合型」と呼ぶ。等価な 格子は三つ存在する。RHEED 像は「整合型」をとる薄 膜のほうが鮮明である。

表 1 およびこれらの結果から, VOPc 分子は分子間距 離約 $1.4 \mathrm{~nm}$ の正方格子を組みやすいととがわかる。 GaSe 上ではこの安定な格子をわずかに丕めるだけで, 下地と整合することができるために，図60ような分子 配列でのエピタキシャル成長が進んだと考えられる。6 回対称基板の上で表面原子を結んでできる四角形の中で は, 図6のような菱形が最も正方形に近いむのである。

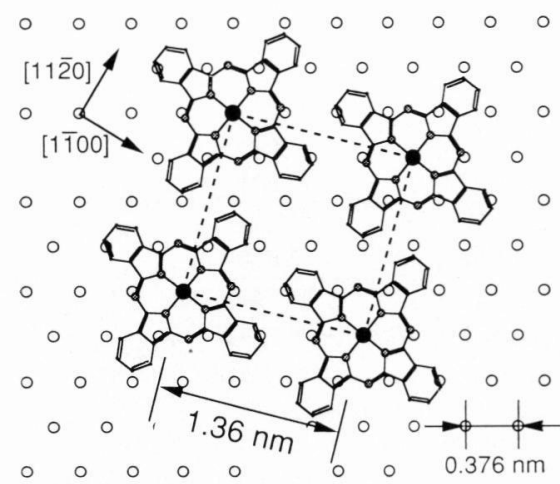

図 $6 \mathrm{GaSe}$ エピタキシャル膜上での $\mathrm{VOPc}$ 分子 の並び方
$\mathrm{MoS}_{2}$ や $\mathrm{NbSe}_{2}$ 上でこの「整合型」菱形格子を組むと, 分子間距離はそれぞれ $1.14 \mathrm{~nm}$ および $1.24 \mathrm{~nm}$ とかな り小さく, 分子間の反発が大きくなり, 整合することに よるエネルギーの利得を上回ると考えられる。「整合型 格子を組めない場合，分子は基板の主軸に沿って並ぶ 「軸平行型」となる。これはおそらく，基板のステップ の影響が現れていると思われる。

\section{$5.3 \mathrm{H}-\mathrm{Si}(111)$ および $\mathrm{Se}-\mathrm{GaAs}(111)$ 面上}

Si や GaAs などの共有結合性 3 次元結晶は，その清 浄表面にダングリングボンドが存在するため, 化学的に 活性で, 多くの有機物は解離吸着または化学吸着をおこ し，規則正しく配列することは難しい。最近，Si (111) 表面のダングリングボンドを水素原子で終端するととに より, 污染や酸化に対して, 不活性な表面が得られるこ とがわかり，半導体プロセスの分野で注目を集めてい る54 56)。また, GaAs(111) 面のダングリングボンドは Se 原子で終端することが有効であることが見出されて いる。これらの表面に, MPc 分子をエピタキシャル成 長した。

VOPc 分子は H-Si (111) 面上で GaSe 上と同じ「整 合型」となる ${ }^{34)}$ 。分子間距離は $1.38 \mathrm{~nm}$ である。AlPc $\mathrm{Cl}$ 分子あ同じ並び方であった。ただし RHEED 像は弱 い。一方, Se-GaAs(111) 面上では, VOPc 分子は分子 間距離 $1.37 \mathrm{~nm}$ の「軸平行型」となる。 Se-GaAs (111) 面 上で整合型」の格子を組む場合の分子間距離は $1.44 \mathrm{~nm}$ となり，VOPcにとって大きすぎるためと考えられる。

以上の実験結果より, 分子と基板との間の格子整合条 件が分子配列を決める重要な要因であることがわかる。 すなわち分子にとって安定な格子上下地基板の原子配列 の間に格子整合がある場合は，格子をわずかであれば歪 ませてでも「整合型」の格子を組む。格子整合が見出せ ない場合は, 分子は適当な分子間距離をとって正方格子 を組む。ただし，その際の分子の配列は基板の主軸に沿 うことが多い。 


\section{6. その他の手法での薄膜の評価}

RHEED では分子の組む格子構造を決めることはで きるが，分子の配向に関する情報を得ることは困難であ る。そこで STM や ARUPS によって分子配向やパッ キングの仕方在調べた。

\section{1 STM}

図 7 は, $\mathrm{MoS}_{2}$ 上に成長した $\mathrm{CuPc}$ 薄膜の STM 像で ある。RHEED では $\mathrm{CuPc}$ 分子は図 5 と同じ「軸平行型」 の正方格子を組んでいることを確かめている。STM 像

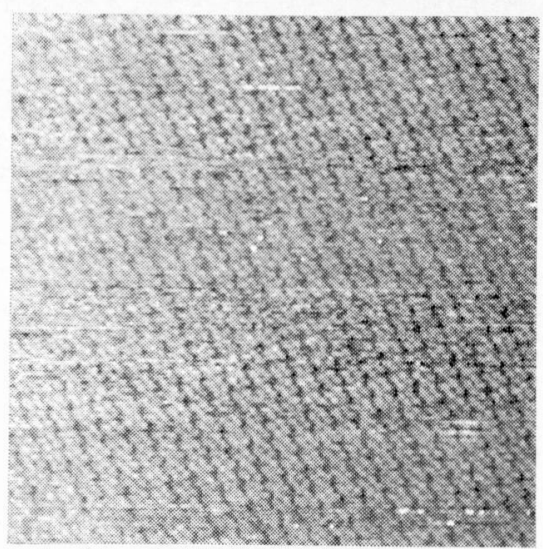

図 $7 \quad \mathrm{MoS}_{2}$ 䢃開面上に成長した $\mathrm{CuPc}$ 超薄膜の STM 像 $(30 \mathrm{~nm} \times 30 \mathrm{~nm})$
では $\mathrm{CuPc}$ の組む格子は正方形からやや丕んでいるが， この違いについてはさらに検討が必要である。ここで重 要なのは，分子が歯車が堛み合うように配列しているこ とである。これは，分子が dove-tail 原理を満たすよう にパッキングしていることを実像として観察したもので ある。

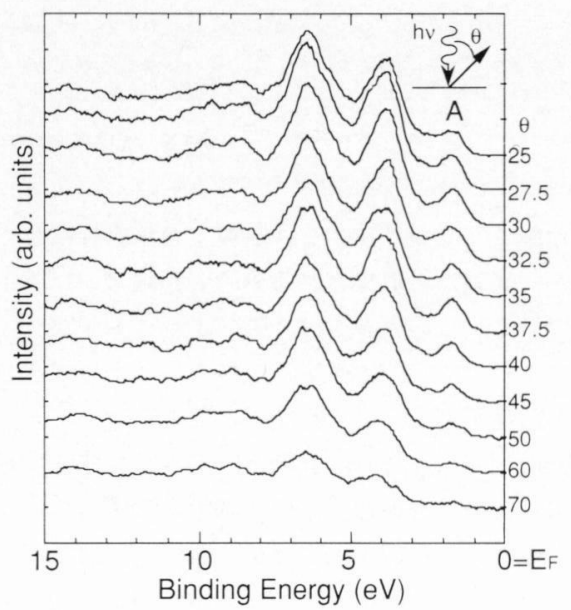

図 8 水素終端 $\mathrm{Si}(111)$ 面上に成長した VOPc 薄 膜 (膜厚約 20 分子層) の角度分解 HeII 光電子 スペクトル

AはVOPc の HOMO バンド

表 2 実験を行った有機分子の成長様式

\begin{tabular}{|c|c|c|c|}
\hline & Alkali halide & $\begin{array}{c}\text { Transition metal } \\
\text { dichalcogenide }\end{array}$ & $\begin{array}{c}\text { Hydrogen- } \\
\text { terminated silicon }\end{array}$ \\
\hline $\mathrm{CuPc}$ & 島状成長 & エピタキシャル成長 & アモルファス \\
\hline $\mathrm{PbPc}$ & エピタキシャル成長 & エピタキシャル成長 & エピタキシャル成長 \\
\hline VOPc & エピタキシャル成長 & エピタキシャル成長 & エピタキシャル成長 \\
\hline $\mathrm{AlPcCl}$ & エピタキシャル成長 & エピタキシャル成長 & エピタキシャル成長 \\
\hline VONc & エピタキシャル成長 & 未実験 & 未実験 \\
\hline DANS & アモルファス & アモルファス & 未実験 \\
\hline MNA & アモルファス & エピタキシャル成長 & 未実験 \\
\hline $\mathrm{Al}-\mathrm{q}_{3}$ & アモルファス & アモルファス & 未実験 \\
\hline coronene & アモルファス & エピタキシャル成長 & アモルファス \\
\hline perylene & アモルファス & エピタキシャル成長 & 未実験 \\
\hline bromanil & アモルファス & アモルファス & 未実験 \\
\hline TM-TTF & アモルファス & エピタキシャル成長 & 未実験 \\
\hline BEDT-TTF & アモルファス & アモルファス & 未実験 \\
\hline TNAP & エピタキシャル成長 & エピタキシャル成長 & 未実験 \\
\hline TF-TCNQ & アモルファス & アモルファス & 未実験 \\
\hline $\mathrm{C}_{60}, \mathrm{C}_{70}$ & 未実験 & エピタキシャル成長 & エピタキシャル成長 \\
\hline
\end{tabular}

alkali halide: $\mathrm{NaCl}, \mathrm{KCl}, \mathrm{KBr}$ etc.

transition [metal dichalcogenide: $\mathrm{MoS}_{2}, \mathrm{MoSe}_{2}$,

$\mathrm{NbSe}_{2}$ etc.

Pc: phthalocyanine

Nc: naphthalocyanine

DANS : 4-dimethyl-amino-4-stilbene
$\mathrm{Al}^{-\mathrm{q}_{3}}$ : hydroxy-quinoline-aluminum MNA : 4-methyl-2-nitro-aniline TM-TTF : tetramethyl-teterathiafulvalene BEDT-TTF : bis (ethylenedithia)-tetrathiafulvalene TNAP : tetracyano-naphthoquinodimethane TF-TCNQ : teterafuloro-tetracyanoquinodimetane 


\section{2 ARUPS}

図 8 は, H-Si (111) 面上にエピタキシャル成長した VOPc 薄膜 (膜厚約 20 分子層) 飞対して, HeII 光源 ( $h \nu$ $=40.8 \mathrm{eV})$ を用いて測定した ARUPS スペクトルであ る $^{37)}$ 。図中Aで示したVOPc の最高被占有軌道 (HOMO) からの光電子放出強度が強い角度依存性をむち, 作製し た薄膜の配向が揃っているととを示している。

分子研の長谷川らは, Grobman によって提出された IAC (Independent Atomic Center) 近似法 ${ }^{57)}$ 用いる ことにより，有機薄膜の ARUPS スペクトルから分子 の配向をかなり定量的に決定できるととを報告してい る ${ }^{58)}$ 。われわれむこの方法にならい, 図 8 の HOMO バン ドの角度依存性を解析したところ，VOPc 分子が分子面 を基板に平行にして配列しているという結論を得た ${ }^{37) 。 ~}$ てれは RHEED による予測を裏付けるあのである。ま た Si (111) 面だけではなく，ほぼ同じ分子間距離をあっ て配列する, $\mathrm{AH}$ 上や $\mathrm{TX}_{2}$ 上であ, 平行配向している ととが推定される。

\section{7. その他の有機分子に関する結果とまとめ}

表 2 にこれまで実験を行った有機薄膜の成長様式をま とめた。アルカリハライド上では, 不対電子を有する窒 素原子を含む有機物がエピタキシャル成長しやすいてと がわかる。また，実験を試みた有機物の多くが遷移金属 ダイカルコゲナイド上では秩序構造をあって配列した。 このうち, コロネンと $\mathrm{C}_{60}{ }^{31,36)}, \mathrm{C}_{70}{ }^{36)}$ そついては, 系統 的に基板の格子定数の影響を調べた。その結果, 有機物 のエピタキシャル成長の要因としてつぎの一般的特徵が あることがわかった。

（1）平面型分子は分子面を基板に平行にして配向す る。

（2）有機分子はできるだけ隙間を少なくするように パッキングして配列する (2 次元 dove-tail 原理)。

（3）その際，分子の組む格子と基板の原子配列との 間に，整合関係がある場合，多少格子を歪めてであ「整 合型」格子となり，エピタキシャル成長が促進される。 この場合, 膜厚数十分子層まで鮮明な RHEED 像が観 察されることが多い。ただし分子間距離は分子にとって 安定な值に収束するため，基板との整合性はなくなる。 これは, TEM や TED による厚い膜に関する結果と一 致している。

（4）ファンデルワールス表面では整合性が満たされ ない場合でもエピタキシャル成長が起てる。その場合, 分子の組む格子の軸は，基板の主軸と一致する「軸平行 型」となるととが多い。乙れはおそらく，分子が基板表 面に存在するステップに沿って配列するためと考えられ
る。

これらの特徴は，数限りない有機物と無機基板物質の 組合せから，エピタキシャル成長に最も適した組合せを 選択する際の指針になると考えられる。

\section{文献}

1) F.L. Carter: "Molecular Electronic Devices" (Marcel Dekker, New York, 1982).

2) L. Royer : Bull. Soc. Franc. Mineral 51, 7 (1928).

3) D. W. Pashley: Advances in Physics 5, 87 (1956).

4) E. Suito, N. Uyeda and M. Ashida: Nature 194, 273 (1962).

5) N. Uyeda, M. Ashida and E. Suito: J. Appl. Phys. 36, 1453 (1965).

6) M. Ashida, N. Uyeda and E. Suito : Bull. Chem. Soc. Jpn. 39, 2616 (1966).

7) M. Ashida: Bull. Chem. Soc. Jpn. 39, 2625 (1966).

8) M. Ashida : Bull. Chem. Soc. Jpn. 39, 2632 (1966).

9) N. Uyeda, T. Kobayashi, E. Suito, Y. Harada and M. Watanabe: J. Appl. Phys. 43, 5181 (1972).

10) H. Saijo, T. Kobayashi and N. Uyeda : J. Cryst. Growth 40, 118 (1977).

11) N. Uyeda, T. Kobayashi, K. Ishizuka and Y. Fujiyoshi : Nature 285, 95 (1980).

12) Y. Ueda and M. Ashida: J. Electron Microsc. 29, 38 (1980).

13) T. Kobayashi, Y. Fujiyoshi, F. Iwatsu and N. Uyeda: Acta Crystallogr. A 37, 692 (1981).

14) T. Kobayashi, Y. Fujiyoshi and N. Uyeda: Acta Crystallogr. A 38, 356 (1982).

15) T. Kobayashi, K. Yase and N. Uyeda: Acta Crystallogr. B 40, 263 (1984).

16) T. Kobayashi, K. Yase and N. Uyeda: J. Cryst. Growth 66, 553 (1984).

17) T. Kobayashi and N. Uyeda : J. Cryst. Growth 84, 589 (1987).

18) H. Yanagi, S. Maeda, S. Hayashi and M. Ashida: J. Cryst. Growth 92, 498 (1988).

19) H. Yanagi, M. Ashida, J. Elbe and D. Wöhrle : J. Phys. Chem. 94, 7056 (1990).

20) H. Yanagi, T. Kouzeki, M. Ashida, T. Noguchi, A. Manivannan, K. Hashimoto and A. Fujishima: J. Appl. Phys. 71, 5146 (1992).

21) S. Isoda, I. Kubo, A. Hoshino, N. Asaka, H. Kurata and T. Kobayashi: J. Cryst. Growth 115, 388 (1991).

22) A. Hoshino, S. Isoda and T. Kobayashi: J. Cryst. Growth 115, 826 (1991).

23) M. Möbus, N. Karl and T. Kobayashi : J. Cryst. Growth 116, 495 (1992).

24) 岡田正和: 応用物理 56, 587 (1987).

25) T. Inoue, K. Yase, K. Inaoka and M. Okada : 
J. Cryst. Growth 83, 306 (1987).

26) K. Yase, S. Ogihara, M. Sano and M. Okada : J. Cryst. Growth 116, 339 (1992).

27) K. Yase, M. Yamanaka, T. Sasaki, K. Inaoka and M. Okada: J. Cryst. Growth 118, 348 (1992).

28) K. Yase, T. Sasaki, M. Yamanaka, T. Inoue, K. Inaoka, Y. Saito, C. Kaito, K. Sato and M. Okada: J. Cryst. Growth 121, 449 (1992).

29) L. E. Firment and G. A. Somorjai : Israel J. Chem 18, 285 (1979), and references therein.

30) H. Tada, K. Saiki and A. Koma : Jpn. J. Appl. Phys. 30, L 306 (1991).

31) M. Sakurai, H. Tada, K. Saiki and A. Koma : Jpn. J. Appl. Phys. 30, L 1892 (1991).

32) 多田博一, 小間 篤: 化学と工業 44, 2109 (1991).

33) H. Tada, K. Saiki and A. Koma : Surf. Sci. 268, 387 (1992).

34) H. Tada, T. Kawaguchi and A. Koma : Appl. Phys. Lett. 61, 2021 (1992).

35) T. Morioka, H. Tada and A. Koma: J. Appl. Phys. 73, 2207 (1993).

36) M. Sakurai, H. Tada, K. Saiki, A. Koma, H. Funasaka and Y. Kishimoto: Chem. Phys. Lett. 208, 425 (1993).

37) H. Tada, T. Kawaguchi and A. Koma: Appl. Surf. Sci. in press.

38) M. Hara, H. Sasabe, A. Yamada and A.F. Garito: Jpn. J. Appl. Phys. 28, L 306 (1989).

39) A. J. Dann, H. Hoshi and Y. Maruyama: J. Appl. Phys. 67, 1371 (1990).

40) H. Hoshi, A. J. Dann and Y. Maruyama: J. Appl. Phys. 67, 6871 (1990).

41) H. Hoshi, Y. Maruyama, H. Masuda and T. Inabe: J. Appl. Phys. 68, 1396 (1990).

42) H. Hoshi and Y. Maruyama : J. Appl. Phys. 69, 3046 (1991).
43) U. Zimmermann and N. Karl: Surf. Sci. 268, 296 (1992).

44) C. Ludwig, B. Gompf, W. Glats, J. Petersen, W. Eisenmenger, M. Möbus, U. Zimmermann and N. Karl : Z. Phys. B 86, 397 (1992).

45) G. E. Collins, K. W. Nebesny, C. D. England, L. -K. Chan, P. A. Lee, B. A. Parkinson and N. R. Armstrong: J. Vac. Sci. Tech. A 10, 2902 (1992).

46) E. I. Haskal, F. F. So, P. E. Burrows and S. R. Forrest: Appl. Phys. Lett. 60, 3223 (1992).

47) W. P. Chang, K. H. Kuo, Y.F. Hou and J.Z. $\mathrm{Ni}$ : J. Solid State Chem. 75, 373 (1988).

48) S. A. Song and D. J. Barber: J. Cryst. Growth 84, 985 (1989).

49) M. V. Zeller and R. G. Hayes: J. Amer. Chem. Soc. 95, 3855 (1973).

50) A.I. Kitaigorodsky: Molecular Crystals and Molecules (Academic Press, New York, 1973).

51) A. Koma : Thin Solid Films 216, 72 (1992), and references therein.

52) K. Ueno, T. Shimada, K. Saiki and A. Koma : Appl. Phys. Lett. 56, 327 (1990).

53) K. Ueno, H. Abe, K. Saiki and A. Koma : J. Vac. Sci. Technol. A 8, 68 (1990).

54) G. S. Higashi, Y. J. Chabal, G. W. Trucks and K. Raghavanchari: Appl. Phys. Lett. 56, 656 (1990).

55) P. Dumas, Y. J. Chabal and P. Jakob : Surf. Sci. 269/270, 867 (1992).

56) S. Watanabe, N. Nakayama and T. Ito: Appl. Phys. Lett. 59, 1458 (1991).

57) W. D. Grobman: Phys. Rev. B 17, 4573 (1978).

58) S. Hasegawa, S. Tanaka, Y. Yamashita, H. Inokuchi, H. Fujimoto, K. Kamiya, K. Seki and N. Ueno: Phys. Rev. B 48, 2596 (1993). 